\title{
The African Independent Apostolic Church's Doctrine under Threat: The Emerging Power of Faith-based Organisations' Interventions and the Johanne Marange Apostolic Church in Zimbabwe
}

\author{
Julius Musevenzi
}

\section{Abstract}

This article analyses the changing and declining influence of the Johanne Marange Apostolic Church's doctrine and belief system over its members' behaviour and conduct. It appears, that this is as a result of the impact of the systematic roll-out of the broad-based biomedical health system, and sexual and reproductive health and rights conscientisation and interventions, by both civil society faith-based organisations and government agencies. Despite the dominance of the more than 70 year old church doctrine (since 1912), its hegemony over its church members has been increasingly challenged over the last two to three decades. Furthermore, this social pressure on the church's beliefs and doctrines, has resulted in what, for the purposes of this article, I call, the emergence of a 'dual doctrine system'. The church beliefs and doctrine were once regarded as impenetrable by outside beliefs, and highly fortified against rival doctrines and their related practices. Yet, it now appears that broad-based health conscientisation and health awareness programmes are systematically eroding the church's doctrine and belief system. They also impact individual members, in so far as some have even been leaving the church. However, the challenge of the hegemony of the church's doctrine and belief system has also seen some, who defend, uphold, and hold fast to their church traditions.

Keywords: Johanne Marange Apostolic Church, doctrine, belief system, biomedical health system, hegemony, dual belief system, dominance 


\section{Introduction}

This paper interrogates the assumed superiority of the Johanne Marange Apostolic church's belief system and doctrine in a changing world. In general, the influence of religion and spirituality in society is weakening due to new forms of knowledge developing around health issues and sexuality. Over the last numbers of years Chitando, Bourdillon, and UNICEF (among others), have reflected on the resilience of the Johanne Marange Apostolic Church's doctrine and belief systems, particularly on issues related to health seeking behaviour, child marriages, the recognition and acceptance of the modern-day health systems, issues related to pregnancy and births as well as child mortality. This article argues that the hegemony and presumed superiority of the Johanne Marange Apostolic Church's beliefs and doctrine, have succumbed to the impact and pressures of the demands of the contemporary modernising and changing world. This is due to especially the impact of the modern biomedical health system and the secular conscientisation of the general populace in Zimbabwe, about personal issues related to sexuality, and human rights. The article traces the pressured departure from the key components of the church's beliefs and doctrine, and believers' behavioural change in their health seeking behaviour. Such a change was unthinkable until a few years ago. The article also highlights the emerging influence and power, civil society knowledge packaging and information dissemination and education has, through civil society networks and awareness programmes. These primarily concern the importance of behaviour change regarding sexuality, and community transformation aimed at modernising health seeking behaviour, in communities dominated by the Johanne Marange Apostolic religious formation. The church beliefs and doctrine were once regarded as impenetrable by outside beliefs, and highly fortified against rival doctrines and their related practices. Yet, it now appears that broad-based health conscientisation and health awareness programmes are systematically eroding the church's doctrine and belief system. They also impact individual members, in so far as some have even been leaving the church. However, the challenge of the hegemony of the church's doctrine and belief system has also seen some, who defend, uphold, and hold fast to their church traditions.

The article is divided into three main sections. Firstly, it provides a brief history of the Johanne Marange Apostolic Church, aspects of its doctrine and belief system, and the social impacts of its accommodation and explicit 
promotion of polygamy and belief in the Holy Spirit. Secondly, the article focuses on the modernising interventions by faith-based organisations, both broad-based and more local and specific. Thirdly follows a brief description of the methodology and fourthly, a thematised discussion of the data gathered in the research.

\section{History and Background}

\section{The History and the Development of the Doctrine and Belief System of the Church}

The founding of the Johanne Marange Apostolic Church in Zimbabwe can be traced back to the 1930s. It is one of the largest African Independent Churches with largely African adherents, blending local traditions with Christianity, with a focus on a ministry of healing. The church was founded and named after its founder, Johanne Marange in 1932. The founder was born in 1912 and died in 1963 in Marange tribal area and his parents were from royal families. According to Daneel (1971), he was originally raised in the Methodist Church. Jules-Rosette (1980) notes that Johanne Marange experienced a divine revelation in July 1932 in which he was called to be Christ's apostle with a distinct missionary mandate. Daneel (1971) similarly highlights that he was given divine messages about the interpretation of the Christian Bible, and its relationship to African customs, specifically Shona traditional rites. In this regard, Daneel shows that the church's doctrine and belief system is rooted in the founder's interpretation of the Bible, in the context of his African tradition. It is told, that it was during this same call, that Johanne Marange received divine power to also perform healing miracles, preach from the Bible, conduct spiritual exorcisms, and speak in tongues. The church has been engaging in the same activities and practices ever since.

The initial growth of the church took place within Johanne Marange's inner and extended family circles (Machingura 2011). Being a member of the royal family, the family influence in the wider society, also paved the way for the spreading of the church. Due to the church's growth and influence, it soon started to play a key role within the Marange communal areas. Today the Johanne Marange religious formation has spread to southern, central, and east Africa, as well as to Europe, particularly the United Kingdom. Already in 2001, Anderson estimated that it had more than ten million members worldwide. The 
church's impact was mainly extended to regions outside Zimbabwe, and into Europe, by migrants. Demographically, in terms of the rural-urban divide, Mukonyora's (1998) analysis about twenty years ago, has shown that about $73 \%$ of the church's membership lived in rural areas, and that around $64 \%$ of the church membership comprised of women, of whom the majority were aged between 20-29 years. At the time of his research, he further found that only around $13 \%$ of the church's membership in this age group, were males.

\section{Aspects of the Church's Doctrine and Belief System}

There is no doubt that the way this apostolic church was founded, determined the crafting of its doctrine and belief system. The same blending of traditional African culture with some Biblical beliefs and practices that Johanne Marange practiced, was extended by the church and its officials. In his study of the movement in 1987, Bourdillon founded that the beliefs of the Marange apostolic formation were indeed centred largely on the teachings of the founder, and minimally influenced by the biblical text. Church members believe that Johanne Marange, the founder, received the church's charter, its rules and practices through the Holy Spirit. Daneel (1971) writes that the church has strict obligations for the Sabbath day, or Saturday, and that members are not allowed to work on that day. They also do not handle money on Saturdays and do not allow members to cook on the Sabbath day. This is in line with the Jewish sabbatical laws in the Bible. The use of alcoholic beverages and the smoking of cigarettes are prohibited, as they are considered as defiling to the body.

Another peculiarity of the church is that members dress in white garments for church services (Leach 1967). Symbolically, it represents purity, light and cleanliness. They do not wear anything black in colour. Both men and women are head shaved as a sign of religious commitment to God. In terms of the church's belief system, this is a visible symbol of the church members' separation from the world. It believes that demons and evil spirits reside in hair and head shaving is a way of getting rid of such spirits. Interestingly, Leach (1967) observes that head shaving represents discipline, self-control and the repression of worldly desires. Men are however, encouraged to have long beards, which are interpreted as a sign of moral authority, reminiscent of the tradition of the Jewish patriarchs. 


\section{Polygamy and Powerless Women as Drivers of the Church's Beliefs}

It has already been pointed out, that women appears to be the majority of members in the Johanne Marange Church. This is so, despite the fact that it accommodates and promotes polygamy. Johanne Marange as the founder of this social movement, had thirteen wives. The church has been promoting polygamy, and polygamous marriage, in line with traditional African as well as ancient Jewish cultural traditions. For support and legitimation of polygamous marriage, the church draws on Biblical examples of the Israelite progenitors of Abraham, Isaac, Jacob, David and Solomon, who are regarded as exemplary forebears of faith in God. Non-theologically and pragmatically speaking, Dillon-Mallone (1978) interestingly shows that polygamy among the Johanne Marange apostolic group, simply fills the gap of the numerical difference of the women to men ratio, and that this is why it is encouraged. Furthermore, while marriage within the apostolic group is encouraged, marriages with non-members are discouraged. This, though, primarily applies to women. Men are allowed to marry women who do not belong to the Johann Marange group, provided the women are prepared to become a member of the group. This practice obviously disadvantages women more than men. Preventing women to marry outside the church, can be seen as a social impediment that exposes women to polygamy, especially since it appears that the number of women to men ratio exceeds that of men to women.

According to research, premarital relations are forbidden. Sexual relations between couples before marriage, are, however allowed if permission from parents have been obtained, and after the prescribed religious ceremonies and rituals have been followed. Premarital purity is guarded by encouraging girls to remain virgins. Muphree (1969) observed that virginity testing is common in the group and those who fail the virginity test are forced into polygamous marriages, and to go and live with older men, together with their wives. Girls who get married as virgins, are encouraged to become head-wives in polygamous marriages, especially if they marry men who had not been married before.

According to Jules-Rosette (1987) women in the church are the bearers of the church's belief system, even though they are not allowed to be church leaders. Women constitute the majority of the membership of the church and are the drivers of the belief system, as the majority of the beliefs of the church 
are directed at them. This makes for a skewed system in which women, even though they do not experience the same freedoms as men, are the bearers of the church's belief system that in fact represses them. As far as we can tell, issues of equality between the sexes have so far not officially been raised in the church. Their status in the church is that of minors particularly with regard to leadership positions, and that actual management and administration and running of the church. This has greatly affected young girls' access to education, as they are married off at an early age. In this regard, Bishau (2010) found a high illiteracy rate among the married women belonging to Johanne Marange, also impacting the level of their health and well-being. Any form of family planning is passionately prohibited by the church, and labelled as devilish. This discursive practice goes so far as to even like women who engage any form of family planning, to murderers. From the brief overview of the issue of polygamy and the status of women in the church above, it is also understandable that this in turn heavily exposes women to HIV and AIDS, in addition to the many other sexually transmitted diseases. This brings us to the issue of the belief in the power of the Holy Spirit, and the role of men.

\section{The Power of the Holy Spirit and the Evilness of the Biomedical Health System}

Gregson et al. (1999) notes that from a religious standpoint the Johanne Marange apostolic group, among other similar groups, regard itself as a spirit type church. This is one of the bases for its religious beliefs and practices. Mbiti (1973) points out that the belief in the Holy Spirit is a key for the church in the sense that it works to nurture and restore good health and quality of life, particularly of those who are faithful and observe the religious tenets, teachings and regulations of the church. He further notes that the Holy Spirit is regarded as the source of spiritual revelation, prophecy, healing and protection and that without it, there is no church. The Holy Spirit serves as the divine force that guides the church, and equips prophets and some church members with special healing powers. Mbiti's (1973) evidence also shows that the belief in the Holy Spirit is seen to ensure strict adherence to religious teachings and practices, and compliance with all normative values of the group. Imposition of penalties on those who violate church regulations and the belief system is a common practice. The beliefs, teachings and practices also tend to reinforce faith in faith 


\section{Julius Musevenzi}

healing and strict adherence to the church doctrine. The concomitant discouragement of the seeking of help and medication from secular biomedical health services, means that the apostolic group has a significant proportion of its membership suffering or dying of conditions which can be easily addressed by medical interventions. It is against the group's dogma to seek medical help from modern medical services and practitioners. The related practice derives from the group's belief that illness and diseases have spiritual and religious undertones, and that these are the primary cause(s) of illness and sickness. Chakawa et al. (2010) add to this argument, pointing out that the church believes that its spiritual interventions have a spiritual competitive edge over secular, modern healthcare services. Thus, there is strong emphasis on adherence to church beliefs, teachings and doctrine on matters pertaining to religion and health. The susceptibility to, and the severity of diseases, are subject to the Holy Spirit and one's faith. And, death from sickness is regarded as the will of God.

In distinction to these beliefs and practices, modern medical services are considered to be 'heathen' and of the devil, and are also deemed as practices which extol human beings above God. It is believed that sin leads to sickness and HIV and AIDS is often linked to sexual sin, adultery, promiscuity or having pre-marital sex. It is believed to be caused by demonic or spiritual forces. At the same time, the presence and prevalence of HIV and AIDS among members is denied. It is regarded as a 'worldly disease' that does not exist among righteous and dedicated apostolic members. The church's belief is that HIV and AIDS can be avoided by marrying virgins or women within the apostolic community and by being faithful and prayerful. The church forbids the use of antiretroviral treatment as well as the use of condoms. This therefore downplays the role of modern medical services since spiritually-related illness require spiritual attention and treatment, that is, the cleansing by the Holy Spirit, holy water or healing rituals in the church.

There is no doubt that the spiritualisation of illness and disease is the main cause for members of the Johanne Marange Apostolic Church to object to the use of modern health facilities. These are perceived to be in conflict with the things of the spirit. When a member accesses modern medical treatment, it is a sign of insufficient faith or trust in God's healing power and intervention. Studies of the church by Chitando (2007) show that the philosophy of faith healing has disastrous consequences for women and children needing medical assistance. Over years, and due to the church's teachings and beliefs, church 
members have sad stories about preventable child deaths and deaths of pregnant mothers in communities, due to a lack of knowledge of child diseases, especially those that could have been easily prevented by vaccines. Children with diseases are quarantined and treated with special concoctions and parents are forbidden to have sex when the child has an illness such as measles, as it is believed that the child might die. In such situations parents have to confess their sin, including adultery, if a sick child is to survive. As a result of the belief system and teachings and due to a high rate of illiteracy, poverty and marginalisation, women are the hardest hit by HIV and AIDS. They are also not equipped to deal with HIV and AIDS, as a result of the level of patriarchy and how sexuality issues are regarded in the church. Phiri (2008) rightfully noted that with the group's anti-modern health methods, women continue to be the victims of polygamy, forced marriages and HIV and AIDS. Women in the church have the highest infection rates and at the same time carry the heavy burden of providing care for the ill and needy. Phiri's analysis shows that this resulted in a number of interventions from mainline churches but with limited success.

\section{Modernising Interventions \\ Church Based Organisations' Health Interventions in Zimbabwe}

Mbona's (2012) study on church interventions in the HIV and AIDS sector shows that the involvement of the church in the provision of medical care dates back to the pre-colonial era. However, focus is on the post-independence period where he acknowledges that the involvement of the church in the health sector developed through three phases. Yet, it still failed to dismantle the apostolic group's hegemony on members' behaviour. The first phase is the complimentary stage between 1985 and 1994. The second phase is the paralleling of the state health-care system between 1995 and 1999. The third phase is the replacement of the responsibility of the state in healthcare, between the years 2000 and 2007. The major participating churches in healthcare provisioning, are the Roman Catholic, Anglican and the Methodist Churches. Their services mainly derived from international donor funding for HIV and AIDS interventions. However, what Mbona (2012) never raised in his study, is that these church interventions were mainly intra-ecclesial and to some 


\section{Julius Musevenzi}

degree in the communities in general. They did not target other churches, particularly the independent apostolic churches.

The church interventions focused on training their own church members in responding to the epidemic and the establishment of the AIDS care and treatment centres in selected rural areas. Biriwasha (2008) acknowledges in his study in Manicaland Province, that the HIV and AIDS interventions by the church sector became important during the period, as the state's health care and welfare system was breaking down and was unable to provide care and support to people infected and affected by the pandemic. The interventions also became critical amid the socio-economic decline of the state. The church community became concerned over the state's economic and social policies that were seen as detrimental to HIV infected and affected people including orphans. As the state invested limited resources in the country's healthcare system, churches took the opportunity to carry the burden of educating and conscientising people, as well as caring for people living with HIV and AIDS.

Mbona's (2012) analysis also shows that the response by these three church denominations brought to light some of the negative reactions by church religious formations, such as denial, stigmatising and discrimination against people infected and affected by HIV and AIDS. To him church followers made a very essential contribution in mitigating the effects of the epidemic. The network of the church and community healthcare systems enhanced access to HIV and AIDS information, awareness, care and the mitigation of the disease especially among rural folk. However, this did not include members of the apostolic church community. In addition, the early church interventions were mainly targeted at home-based care, HIV and AIDS awareness education, orphans care, psychosocial support and income generation support, ignoring key issues such as the need for behaviour change, and the need for departing from detrimental church doctrines and belief systems. Most interventions were implemented through volunteerism, but it was criticised as many church volunteers considered it an opening and prospect of earning money and obtaining household supplies including food. Despite some of these achievements the church community was also criticised for not being safe spaces for discussing health, sexuality and AIDS as it was considered culturally taboo. Whilst intervening, the issue was also raised that the same church that intervenes, often did not open up as to the HIV and AIDS status of its own members. On this score, Mbona's (2011) study also provides some good insight into church intervention failures, as he acknowledges that 
the prevention of sexually transmitted HIV particularly in Manicaland Province, remained undermined by cultural traditions as well as Christian beliefs and practices.

\section{Broadened and Specific Interventions}

The socio-economic decline and political tension between the period 2000 and 2007 in Zimbabwe led to the withdrawal of direct donor funding and support to the state (DFiD 2009). This opened new opportunities for civil society and the faith-based organisations and the church to take a leading role in responding to HIV and AIDS issues. Donor support targeted civil society and key interventions became broad, and focused on the prevention and treatment of HIV and AIDS, maternal and new born health support to reduce further transmission, and behaviour change programmes targeting all age groups and all churches including the apostolic groups that were excluded in previous years. As the interventions became broadened, the emphasis was on the understanding that HIV and AIDS had become more than a health problem as it was decimating families and communities. These are the interventions that form the basis of the weakening of the doctrine and church belief system of the Johanne Marange Apostolic religious formation. Over the years the church's belief system has been believed to be key in the spread of HIV among members and worsened the situation, by the refusal to seek biomedical treatment for those infected. The broadening of the biomedical healthcare services by faithbased organisations' interventions are directly attributed to the challenging and weakening of the Johanne Marange Apostolic Church's members' adherence to the church's doctrine and belief system.

\section{Methods and Materials}

A multi-method approach that employs a triangulation of qualitative research methods was used for the study. Apart from observation, it also included two participatory data gathering techniques aimed at assisting members to own the information they provide. The two instruments used, also ensured that the information provided, is relevant to the topic studied. The qualitative methods, then enabled a more in-depth gathering and examination of qualitative data, especially as it relates to church members' behaviour changes with regard to 
the traditions, beliefs and doctrines of the church. The internal method used was observation, and the two external methods used, were individual, one-onone, in-depth interviews; and focus group discussions (FGDs).

Interviews - A total of 66 ( 44 women and 22 men) interviews were conducted with relevant Church Pastors from the Methodist Church in Zimbabwe, The Johann Marange Apostolic Church, Mugodhi Apostolic Church, Traditional Leaders, and influential community leaders, such as councillors, and key stakeholders at the, provincial and district levels.

Focus Group Discussions (FDGs) - A total of nine FDGs involved community members from different churches in Bikita and the Marange area, also including some community members more generally. A total of four FGDs were conducted in Bikita whilst Mutare district had five. The group sizes ranged between 15 and 26 people in both areas. In Bikita district three FGDs were composed mixed adults ranging from the age of 18 and 76 and one FGD was only composed of youths and teen mothers aged between 15 and 20 years. In Mutare three FGDs were composed of mixed adults whilst the other two were composed of youths and teen mothers aged between 15 and 20 years. FDGs compliment the observation and interview methods, in so far as they provide a generalised discussion among church and community members on the topics covered in the interviews and the focuses in the observation. They also provided information on the improved health status of Johanne Marange female church members who have started to access the various faith-based organisations and the state's health services awareness campaigns, and clinics, over the last decade.

\section{Findings and Discussion}

\section{Inclusive Interventions Targeting the Church Community}

Interviews with FBO members show that the intervention approaches used by many faith-based non-governmental organisations targeting different churches in the two districts of Mutare and Bikita (Zimbabwe) are 1) the Safer (Sex) Practices approach; 2) the Access to Health advocacy approach; 3) the 
Voluntary Testing, Counselling and Empowerment (SAVE) approach; and 4) the UMOJA approach, which is a spiritual and pro-social approach also focused on enhancing life skills and social inclusiveness in community development work. Officials from the Family Aids Caring Trust (FACT) indicated that these approaches have been deployed amongst churches and communities in Manicaland Province. Following training and capacity building, the implementation of these approaches sparked the increased participation of both mainline and African Independent churches and their members, as well as the broader community, in responsively engaging initiatives targeting community needs. Data from interviews show that all the churches involved, both mainline and African independent, contributed to the improving of the sharing of information and the dispelling of misconceptions around various church doctrines and beliefs about HIV and AIDS. The Programme Manager from FACT highlighted that the fact that the training involved religious leaders from different churches, together, made it acceptable to most African independent churches, particularly the Johanne Marange. This is significant, because, in previous years, it was labelled as 'adversative' to HIV awareness and conscientising initiatives, particularly with regard to the preventative methods to used to curb HIV transmission.

Study findings show that all churches in the study area were targeted as entry points for addressing the silence about HIV and AIDS, and challenging stigma and discrimination not only in the church, but also in the community at large. For FBO officials churches became a focus because they are comparatively permanent structures in the community, thus providing an ideal entry point and launch-pad for inclusive interventions in an ever-widening geographical area. Unlike political leaders (such as councillors and members of parliaments) who come and go, churches have in most cases continuity, and this is relevant for addressing issues of HIV and AIDS and health more generally speaking.

\section{Community Level Agents of Change a Threat to the Independent Apostolic Church Doctrines}

The study findings show that the capacity building of care facilitators as change agents at the community level targeting church members for diluting the adverse church beliefs, was instrumental in the shift from doctrinal adherence 


\section{Julius Musevenzi}

to health accommodation, by members of the Johanne Marange Apostolic Church. Interviews with care facilitators showed that as change agents they ensured that people living with HIV and AIDS from the community and from the apostolic churches were not only encouraged to access treatment, but that they also adhere to the prescribed treatment consistently.

Evidence from FGDs with community and church members in Bikita shows that the role of these change agents has contributed to not only a shift away from the church doctrine and belief system but to a dual behaviour by church members, where, during the night they use modern medication for treatment, and during the day they subscribe to the discursive practices of the church.

One woman had this to say:

After being ill for a long time, getting holy water and going through prayers, my condition never changed but was rather getting worse. The visit by care facilitators made me seek medication and with their assistance I had no option but to try new ways of addressing my health concerns. Within two months of taking medication I had fully recovered and I owe my life to these care facilitators, who changed it on a day's visit.

The quotation shows the impact of the change agents on apostolic church members who were bed ridden and suffering from HIV and AIDS.

A glance at the statistics from selected local health centres in both districts also show a reduced rate of HIV related deaths, from an average of 11 people per month in 2009, to three people in three months by end of December 2014. This is in a community dominated by the Johanne Marange Apostolic Church and these statistics signify an increased uptake of modern health medication by members of the group. Evidence from interviews in both districts show that empowered through workshops and trainings on palliative care, psychosocial support and also knowledge and information sharing on both communicable and non-communicable diseases, these change agents have become drivers of community change. The result is that many people have started to access the health services and medication, including condom use, by both adults and youths. This practice has also started to challenge the 70-year old church doctrine and a belief system of the Johanne Marange Apostolic Church. 
Data from FGDs with community members in Mutare show that members of the group who are living with HIV and AIDS learnt to disclose their status and be open about their HIV status. They have also learnt the importance of the access of treatment and medication, and the eating of healthy food. Moreover, evidence of Johanne Marange members participating in support groups made up of church members as well as non-church members, for strengthening and supporting each other - socially, but also with regard to information and knowledge sharing - is a direct challenge to the church belief system. These have replaced reliance on the 'power of the Holy Spirit' indicating the beliefs and doctrines of the church - on their supporting social group(s) and its network(s). They have experienced both social and medical empowerment, i.e. to not only manage their own illness and status, but also to assist others who suffer from this dreadful disease.

\section{Empowering Youth and Teen Mothers on Sexual and Reproductive Health Issues}

Data from interviews with FBO officials in both districts show that targeting the younger generation, the faith-based organisations established Youthfriendly corners in the study areas. These have become symbols of youth empowerment, but also an implicit threat, countering the Johanne Marange church's doctrine and belief system. Interviews with Youth Officers in both districts show that the Youth-friendly centres are meant to assist the youth with relevant information to protect themselves and to be correctly informed by HIV and AIDS, as well as STDs. From the FBO's perspective, the main focus is to dispel any misconceptions regarding these kinds of infections and their religious beliefs do not accommodate modern-day healthcare. Evidence from FGDs with youth groups in Mutare show that some of the youths from the Johanne Marange social formation and the community in general living with HIV and AIDS, had their knowledge improved after accessing information, treatment and particularly the importance of the adherence to the taking of prescribed medicine, as well as sexual reproductive health issues. Similarly, as a platform for information sharing on HIV, access to sexual reproductive health services and tactical disclosure youth support groups were established throughout the districts. This has made a visible impact in giving hope among youths in the rural districts, and, for them, to amend their beliefs in Johanne 


\section{Julius Musevenzi}

Marange, that prohibits the accessing of such information and medicines. This became an empowerment tool to especially young girls, who are largely vulnerable to the church belief system through its patriarchal beliefs, practices, and its enforcing of early or girl-child marriages.

Tactically targeting teen mothers with HIV and AIDS, with Sexual and Reproductive Health (SRH) information and knowledge, has empowered them to make informed choices and to become more self-reliant. It has also started to explicitly challenge the dominance of men from the church, as the source of information regarding social and sexual life and health. Data from FACT field officials shows that teen mothers is a group whose needs have been inadequately addressed and in most cases are marginalised not only in the church but also in communities which perceive them as illegitimate mothers and young mothers who failed to abide by the church doctrine. The society has forms of motherhood that are recognised and others that are despised due to the perceived violation of norms and values and this is also reflected in the Johanne Marange Apostolic Church. Information from FGDs with youths and teen mothers reflect teen mothers as vulnerable not only to HIV but also to unplanned repeat pregnancies as well, whilst in the church, the non-virgins are married off to older men to become young wives. Data from interviews with FBO officers gave a positive impression that targeting church married and unmarried teen mothers has been relevant in addressing the needs of a hidden yet vulnerable group, which out of desperation may engage in transactional sex and trans-generational marriage. This inevitably challenges the hegemony of the church doctrine regarding the position of women and particularly young women in the church and community.

For most intervening FBOs targeting a stigmatised group, enables faith-based organisations to assist them in constructively engaging practices that affect them, or to access information and services, such as SRH information and services. Distribution of condoms has also been a relevant intervention targeting the youth. NAC (2012) statistics show that despite Zimbabwe recording an increased uptake of condoms, the uptake has been very low among youths and very high among adults giving an uptake ratio of $9 \%$ and $91 \%$ respectively by end of 2014 . Evidence from the Mutare district, Mafararikwa health clinic, shows that some of the youths are shy to come and collect condoms on their own, but that they do send others to collect the condoms for them. Even though the percentage precedence of youth in the area that rely on this practice to acquire condoms, cannot be ascertained, it does 
signify a change in the belief system, and equally, accessing modern-day systems for their protection and health.

\section{Behaviour Change Strategies}

Interviews with FBO officials from FACT in both districts presented targeted voluntary counselling and testing for HIV and AIDS and STDs as one of the main strategies of the faith-based organisations aimed at behaviour change among members of the different churches and the community more generally speaking, particularly youths and teen mothers. A review of the training material and reports show that through behaviour change strategies, the marginalised groups of teen mothers from the apostolic church community were trained in sexual reproductive health and HIV issues, as well as the cultivation of sustainable livelihoods. This was aimed at enriching them with modern knowledge on health issues, and changing practices related to sexual behaviour. It was also aimed at transitioning them from the church belief system type of knowledge, to a secular, information and knowledge type of knowledge based on independent thinking. This also challenged the supremacy of male dominance over women, especially teenage girls, as per the church's doctrine.

Data gathered from FGDs in both districts with both adults and youths show that the immediate results of the interventions were the reduction of repeat cases teen mothers falling pregnant outside marriage, and delayed marriages in the church. This, in a way, was a direct challenge to the polygamous doctrine in the church where non-virgin girls are married to already married older men. In such situations a second wife or third wife is less influential than the first wife. Teen mothers became empowered by looking for men outside the church and this was achieved through delayed marriages and the avoidance of getting pregnant outside marriage. This type of behaviour change also contributed to reduced new infections of HIV among youths and teen mothers within the Johanne Marange Apostolic group. Condom uptake and use among youths and teen mothers from the apostolic church community also increased. The findings show that behaviour change was also coupled with improved knowledge on condom use, so as to reduce new HIV infections and STIs, including unwanted teen pregnancies. With regard to how condoms are used, most people interviewed, including youths, indicated that they are 
knowledgeable in how to use them, indicating that the collection of condoms from the Youth corners is resulting in the actual use of the condoms.

\section{Mothers' Shelter and Youth-Friendly Corners as Infrastructure Interventions}

Interview discussions with Government officials in Bikita district show that about a decade or more ago, faith-based organisations, in cooperation with the government, have embarked on infrastructure development. Such infrastructure development was mostly aimed at the establishing of Mother's Shelters and the Youth Corners. Mainline churches, and the leaderships of community organisations mobilised resources for the construction of the Mothers' Shelters and the Youth Corners, in both Mutare and Bikita districts, to serve as knowledge and service centres. The Mothers' Shelters aim at reproductive health education and training of women and girls, educating and teaching pregnant mothers about their condition, monitoring and assisting them with regard to the developing of their pregnancy, and with the actual delivery of the baby in a safe environment. They also cater for post-natal care of both mother and child. As such, the Mothers' Shelters have been aiming at the reduction of the number of home deliveries and the closely-related neo-natal and maternal deaths. The practice in the Johanne Marange is that it is usually older women who serve as midwifes. The services of the Youth Corners have been referred to already.

Data from FGDs with members of different churches show that the actual building of these buildings at targeted clinics saw the churches and the different communities contributing with the provision of bricks, cement, sand and labour, as well as land clearing particularly in Bikita district. Collaboration with the line government department of public works saw technical and logistical support being provided by government. The construction and founding of these centres feed into the broader national health priorities and infrastructure development of the country. While they transformatively impacted on the increase in the health of pregnant mothers, the safe delivery of babies, and the reduction neo-natal deaths and mothers dying during child birth, amongst others, they have also become a symbol of challenge to the Johanne Marange doctrine and beliefs. Even so, they have also contributed to the change in mind-set of most of the targeted apostolic church members 
regarding health seeking behaviour. These centres and infrastructure are now being used either secretly or openly by members of the Johanne Marange Apostolic church. Most of the members of church leadership are also accessing the services secretly whilst general members are accessing them openly.

With regard to the youth-friendly centres, information and knowledge shared here, the study findings show that focus was at portraying youths as active agents in managing their own health and accessing of health and medical systems, and not to 'trust in the Holy Spirit'. At some clinics television sets and Digital Video Disc Players are also used to enhance visual learning as one of the effective educational and transformative tools employed for the behaviour change of youths.

\section{Emerging Modern Health Seeking Behaviour among Church Members}

Statistics from FACT and the Catholic Diocese of Mutare show that interventions in Mutare and Bikita districts targeted 206 churches and assemblies of different churches - Bikita102; Mutare 104. Reaching a total of 2416 people (746 men and 1670 women), of this total, Bikita had 1150 people and Mutare 1266 people participating in the interventions, with the majority coming from African Independent Apostolic churches. The statistics from the FBO records show that about $40 \%$ of the community people reached, disclosed their their HIV status in their churches, excluding the Johanne Marange Apostolic religious formation. Of the $40 \%$ of people who disclosed their status, about $28 \%$ were women. This is significant considering that women in these churches are most vulnerable. However, for the Johanne Marange group, women have not been disclosing thier status. Many though have been accessing treatment and information secretly - behind the back of their church leadership so to speak. This has lead to the dual doctrine system. Of the dual doctrines one is discreet and secretive, and the other open to society. However, the discreet and secretive doctrine of modern health and knowledge seeking behaviour, is growing fast, challenging the once dominant church doctrine. Of those church members who do nto come from the Joahnne Marange church, who have participated in the interventions, the study shows, that about $40 \%$, disclosed their HIV status, in their churches, excluding the Johanne Marange Church. With regard to the latter, in the two districts dominated by the Johanne 
Marange religious formation, there is now a climate of acceptance and of accessing the modern biomedical health system in contradiction, to beliefs and doctrines propagated by the church.

One middle aged woman from the Vadzidzi Apostolic Church in Bikita had this to say:

It used to be taboo to talk about HIV and AIDS in our church but these days our church leaders have accepted it as a reality and are now allowing church members to openly share and discuss it, to prevent deaths that can be prevented by seeking biomedical health treatment.

The above words reflect the flexibility of other churches in quickly adapting to the FBO interventions regarding seeking biomedical hgealth support and changes in sexual as well as behaviour patterns.

According to our study findings, a total of eight apostolic churches (3 in Bikita and 5 in Mutare) have established support groups for people living with HIV and AIDS, in order to assist individuals in managing their HIV and AIDS status. Whilst moderate apostolic churches such as Habakook, Vadzidzi among others had no challenges in accepting health-related interventions within their churches, members of the Johanne Marange are accessing treatment, knowledge on HIV and AIDS, condoms either secretly our via members of other churches, or through community members in general. They do not disclose to their church leadership that they are participating in health related programmes. Thus, whilst other churches are accepting and linking their churches to local health centres and clinics with regards to the accessing of medical services, and support of their membership living with HIV and AIDS, the Johanne Marange has its doctrine and belief system quietly challenged by its members who are accessing modern biomedical health services secretively. Evidence from FGDs conducted in Bikita show that the group's members' voluntary accessing of counselling and testing services and treatment, as well as the provision of Youth-friendly corners, is now irreversible. As such, it is impacting the church's traditional doctrine and impact, with regard to health and wellness in these two traditional areas of support.

The study shows that, over the last number of years, some of the African Independent Apostolic churches have started to acknowledge that their members have HIV and AIDS, and have been dying of Aids. They have also 
become much more aware of the fact that HIV is spread through having multiple and con-current sexual partnerships. This has been one of the key drivers of HIV infection in these churches. However, data from FGDs with community and church members Mutare show that in the Johanne Marange group, it is still taboo to talk openly about HIV and Aids, as well as STDs for that matter.

One middle aged man from the Johanne Marange in Mutare had this to say:

Before I got married I lost two brothers who had six and four wives each. Through these community interventions I realised that the main cause was HIV and AIDS. From then I made a decision that I was going to marry one wife against the church's doctrine and after all it's a choice and here I am, I have three children and going very strong.

This quotation reflects a change in sexual behaviour by not only women from the Johanne Marange Church but also men who are moving away from the doctrine of marrying multiple wives.

Study findings show that there is a rising number of members who are challenging the belief and doctrinal practices though. Statistics at selected clinics such as Zvipiripiri and Dewure Rural Health Centres in Bikita district showed an increase in the uptake of medical health seeking services from more than 558 women in one year from the Johanne Marange Apostolic church indicating a change towards health seeking behaviour. This change is taking place without the church's support. Its official position still constrains individuals from health seeking behaviour. Increasingly, the group's members are on the list of ART clients tough. Some have also started to visit the centres seeking treatment for STI's.

So, the study evidence shows that the intervention on health seeking behaviour have impacted many of the indigenous Independent African churches. In addition to the Johanne Marange, there are some church who, as yet, do not openly encourage their members to seek out medical help and health services. These include, the Johanne Masowe, and the Jowane Masowe Chishanu churches. The churches who overtly propagate the seeking of health services and who encourage their members to seek help, include, the Mugodhi, Kusangana Kwevapostori, Chitenderano Chevapostori, Zion City, Chitenderano 2, and Zviratidzo Zvevapositori churches. Evidevnce from FGDs 


\section{Julius Musevenzi}

in Mutare show that these latter churches also opened their doors for the open discussion of illness and health issues, especially HIV and AIDS, in the church, and to become health change agents. This demonstrates such health interventions have started to become accepted by some churches, and many have stopped dissuading their members from embracing biomedicine. Apart from the ecumenical participation in the establishing of the health and medical centres, this has also been made possible by twinning participants from apostolic churches with members from mainline churches such as the Roman Catholic, United Methodist, The Baptist, Evangelical, Anglican and Seventh Day Adventist amongst a host of churches, to become change agents at the community level.

In the research, as evidenced by health centres statistics, changes were also recorded on the number of people who visited rural clinics, particularly pregnant mothers from the Johanne Marange apostolic group. Before these interventions started, there were only two such visits recorded. There have been a substantial increase in these numbers over the last number of years in the two districts, due to the interventions. From the interviews, we can mention the following.

One elderly lady from the Johanne Marange had this to say:

Nearly all my sons and daughters have died and I did not know the cause. I am looking after my nine grandsons and granddaughters. I was advised to seek treatment a year ago for the three who were always sick. I went to the clinic and now they get medication and they have changed and improved greatly and they are going to school without problems. I have not communicated this to my church because I am the one who was suffering with their sickness while the church was only praying for them, but with no improvements.

This quotation is only one example of health seeking behaviour change at the individual level where an individual member has sought medical treatment without the knowledge of the church leadership.

With regard to the increased health of the general population in the districts, due to the HIV and Aids counselling and the increase in the general health of the people visiting the health centre, one female care giver in Mafararikwa in Mutare rural district, even said, 'Gloves are no longer being used to touch people, because people are no longer bed ridden unlike before'. 
In the centres, pregnant women who are found to be HIV positive, are put on treatment to avoid mother-to-child transmission of the virus. This contributes to the national target of zero new infections.

Another important intervention is to have care facilitators reaching out to people living with HIV and AIDS, by ensuring that they adhere to treatment as per their prescriptions. Data from interviews with care facilitators show that nn average, each care facilitator supports between twelve (12) and fifteen (15) people around his or her village, offering care to the sick and encouraging the seeking of early treatment as well as adherence to treatment.

Amongst many others, these changes reflect the importance of the role played by change agents at the community level regarding challenging the church doctrine and belief systems of the established and entrenched belief and doctrinal systems with regard to their spiritualising of the physical and empirical health of their members.

\section{The New Dual Doctrine and Belief System}

The research on which the current study draws, revealed that the broad-based interventions of the centres and clinics made both direct and indirect contributions to the adoption of the modern health system and related behaviour change, especially regarding sexuality. This resulted in many church members now simply believing in and practicing two virtually exclusive belief and doctrinal systems, one for the church with, some aspects of the system not being followed, and the other, the modern health system, premised on belief and behaviour change. This has resulted in the dual doctrine system being followed by Johanne Marange apostolic group members and also by members of the Johanne Masowe, and the Jowanne Masowe Chishanu. The emergence of the dual doctrine system has contributed to the reduction of new infections through behaviour change. From the statistical data given in the previous sections the study shows a great change or impact of the dual doctrine system largely among women as a target group, as they are the majority in these churches, and the most vulnerable.

In Mutare, the rural Johanne Marange Apostolic Church has more than 10000 followers and nationally, it has close to a million followers. It is estimated that about $40 \%$ of the 10000 members were positively impacted by the broad-based interventions. Most of the church leaders trained, are women, 
and they have reached out to fellow women and girls in both districts. The trainings contributed to dispelling misconceptions that the church community had on HIV issues. The mainline churches who were most helpful in the training of these members, are the Seventh Day Adventist, Methodist Church, and Anglican among others. One elderly lady from Johanne Marange said:

Over the years we were in darkness as a church; most of us in the church are now seeking HIV knowledge from other churches and now secretly go for HIV testing, and also access treatment without the knowledge of our church leadership. I personally referred 16 people who were once bed ridden, for testing and ART treatment and they are now up and running again.

This shows that trained church leaders have impacted the mindsets of apostolic group members, towards health seeking behaviour. Their uptake of health services demonstrates the change amongst traditional churches that traditionally have not accessed the services of hospitals and clinics, such as Johanne Marange. The study also found that more and more people get empowered and that many have learnt to manage their HIV status. It has significantly improved the general health of the people in the districts, and also translated into improved health status of largely women. Although the fact of members seeking health services secretly and that those taking medication secretly, is still worrying, that they have started to challenge traditional church doctrine and its anti-conventional medical treatment, is brave. Not all members are doing it though, and many members continue to live with HIV and its infections, facing death, out of fear of being socially ostracised at church. One young lady, member of the Johanne Marange apostolic group in Mutare said:

I am the $17^{\text {th }}$ wife of an old man and I had gone for more than 18 months without engaging sexually with the old man, I resorted to young men of my age for sexual satisfaction and when I became sick I was advised by an aunt from the Methodist church to go for testing and I was found positive and I am now on treatment for the past two years. The old man came to have sex with me during the $19^{\text {th }}$ month and out of fear I did not tell him because he is one of the senior members of the church, so he might have contracted and transmitted HIV to the rest of his wives. 
Amongst others, this quotation just shows that the battle against HIV and Aids, as well as the general improvement of the health and wellness of the population is complex. Yet, the push for greater and more widespread impact of the dissemination of information and education must go on.

\section{The Church Doctrine versus the Condom Doctrine}

Finally, I reflect on this very important matter. The research findings have shown that youths and church members have not completely abandoned the church doctrine but that many have embraced the condom doctrine together with the church doctrine. The condom doctrine is however, growing, whilst the church doctrine is being used for identity purposes. The growing of the condom doctrine is evidenced in the increased uptake of condom-use, which also indicates behaviour change. The result is also evidenced in a presumably decrease in the number of HIV infections and the number of Aids deaths, as referred to above. We have also detected an increase in health seeking behaviour, particularly the increase in the seeking of reproductive health information among youth, contacting the youth-friendly centres. The following bar graph shows the growth in the condom distribution interventions over a four year period in the study area.

\section{Graph 1: Community level Uptake of Condoms}

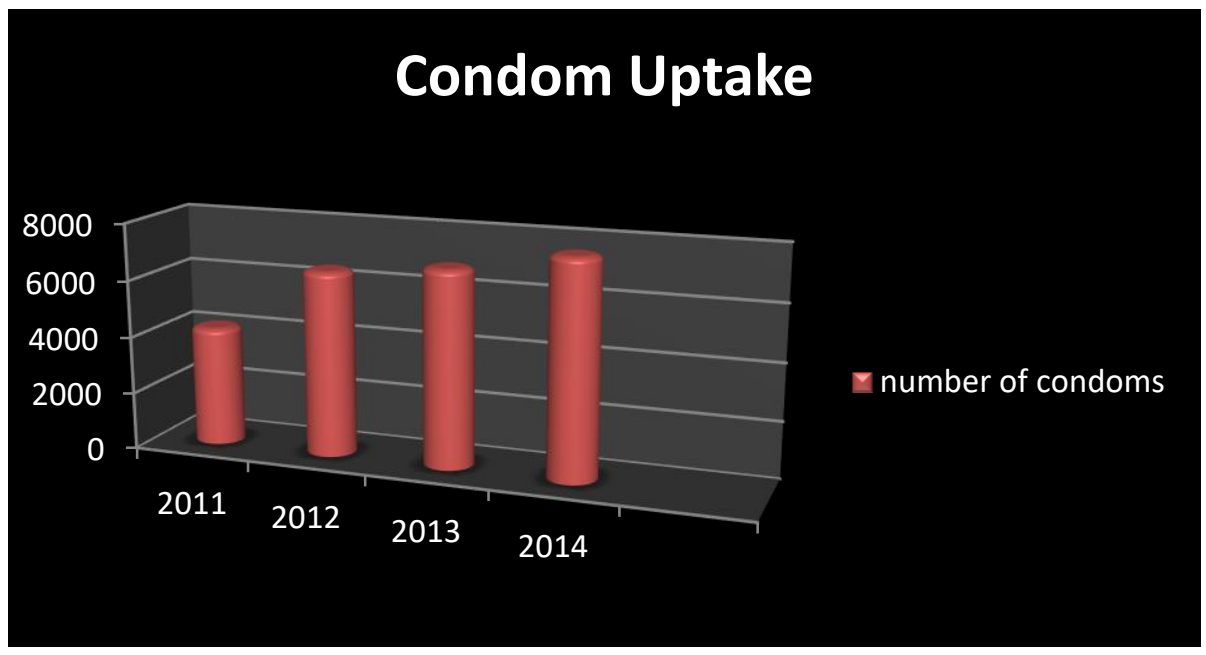




\section{Julius Musevenzi}

The bar graph shows a gradual increase of condom uptake and use since the start of the broad interventions in 2011. In 2011, below 4000 condoms were used but by the end of 2013 more than 7000 condoms were taken up. This signifies a general improvement in behaviour change towards prevention and safer sexual practices in both districts. The increase in the uptake of condoms also shows that people have more knowledge on the use of condoms in the prevention of the HIV virus. It may also show an increase in the prevalence of the dual doctrine system.

In terms of behaviour change, there is one surprising statistic. From the health centres visited for the study, it appears that about $90 \%$ of the condom uptake comes from adult males in the age-group, $25-55$. Whilst the main campaign for condom usage is aimed at youths, ranging from boys in their late teens to young adult males, up to the age of 25 , only around $10 \%$ of the uptake of condoms come from these age groups. Evidence from local health staff indicated that this is influenced by not only fear, but also shyness by youths, i.e. to directly collect condoms from the designated collection sites in communities dominated by the Johanne Marange Apostolic group's doctrine. It was reported that boys in their late teens and young adult males are shy to collect condoms from the health centres, where there are mostly only female nurses on duty. Many roam around the centres, without entering and asking for the condoms. However, the perception of the lower uptake of condoms among the younger generation does not mean that they are not changing their behaviour towards safer sexual practices. It appears that some are indeed accessing condoms by buying them from shops or collect them from public places such as toilets in townships. Evidence also suggests that older men do collect condoms for the younger men from the health centres.

One youth in an FGD in Bikita had this to say:

We as youths do not openly collect condoms from public places but we sometimes sent our brothers and senior friends to collect on our behalf, so some of those who collect condoms from local health centres may not be the direct users but us youths who are behind the scenes.

The above quotation shows that not all collectors of condoms from public places are the final consumers of the same but youths who are operating from behind the scenes are also consumers although the percentage could not be ascertained. 
For those who are living with HIV, the main behavioural change has been in accessing treatment and ARVs. Comparatively more women are accessing treatment than men, as well as being inclined towards health seeking behaviour. According to NAC (2012) more men are dying of HIV and AIDS in Zimbabwe compared to women, although more women are infected and this corroborates with the findings of the research, regarding the greater flexibility of women regarding behaviour change. Percentage wise, more women in the study have shown relevant knowledge about HIV and AIDS, and STDs, and also that they have changed their behaviour, towards positive living and safer sexual practices. Increased knowledge levels among girls are also attributed to the youth-friendly corner interventions. These have also dramatically impacted the reduction of STI cases among unmarried youths. The local health centre nurses also reported that one of the main challenges that remain, is the comparably large number of STI infections still prevalent among married people.

\section{Conclusions}

In Zimbabwe, the doctrines and belief systems of extreme Independent African groups such as the Johanne Marange, Vadzidzi, Jowane Masowe Chisano have been perpetuating doctrines that continue allowing for the spreading of HIV and AIDS, increase child mortality rates, deaths related to child births, child marriages and general deaths rates due to the non-seeking of biomedical health system. The rate of HIV mother to child transmissions, is wholly unknown. The study concludes that whilst the doctrine and belief system is still relatively strong, it has been significantly challenged by broad-based biomedical health interventions, and the increased bio-medical health system adoption, health seeking behaviour change, assertion of sexual and reproductive health rights, and changes in traditional perceptions of sexuality. It has become clear that the basic doctrine of the Johanne Marange Apostolic church in both Mutare and Bikita districts, that prohibits health seeking behaviour, is losing its dominance. This is due to the emergence of a dual doctrine system that church members have started to practice, i.e. to recognise both the church belief system and the bio-medical health system. The rising statistics of members who engage in health seeking behaviour, and the concomitant stress on the doctrinal system augurs well for the future health of the community. 
Broad-based interventions, in which faith-based organisations partnered with government were implemented in the two study areas since 2011. Promoting health seeking behaviour, and the seeking of biomedical treatment, they have been challenging the dominance and the influence of the Johanne Marange Apostolic group's doctrine of 'depending on the Holy Spirit' for one's health, and the impact of polygamy on the spreading of HIV and Aids, as well as STIs. To most church members, by adopting health seeking behaviour, they are gaining enlightenment concerning illness and sickness, contrary to the views and beliefs they are taught in the church regularly. The vulnerability of women in the church, who are the majority members of the church has emerged as the stepping stone to the dual doctrine system that in fact reduces the burden of illness and the care of the ill. The study also revealed that the Mothers' Shelters and the Youth Corners have become symbols of freedom, knowledge and enlightenment. Their services, ranging from education on reproductive health issues, to the hosting of pregnant mothers and the delivery babies, to the increasing distribution of condoms, are also important to take note of. The study has also revealed that the majority of church members have started to access the health services these centres offer, even though secretly.

The role played by interventions in the study areas appears irreversible as the emergence of the dual doctrine system has diluted the 70 year old church doctrine and its grip on the behaviour of members. In particular, it appears that its grip on the youth, especially young girls and young pregnant mothers is on the decline. The older generation still appears to hold fast to the church's closed doctrinal system. Yet, it is the younger generation that has started with health seeking behaviour and the accessing of health services. Furthermore, as this study has shown, the cooperation of faith-based organisations - also including some prominent mainline churches - with government on the one hand, and their twinning with specific African Independent Churches, appears to be a very helpful model, that may yet prove helpful in the assistance and facilitation of the indigenous churches starting to encourage health seeking behaviour among their members. It is hoped that, what I have called the emergence of the dual doctrine system', will also disappear in time. For this to happen, the continued rolling out of the health services to the more traditional communities in Zimbabwe, as well as elsewhere, by the relevant agencies need to be continued and stepped up. As indicated, this will continue to impact the general health and wellness of the community, reduce HIV and Aids infections, 
improve the healthcare for people living with Aids through access to ARVs, reduce deaths due to Aids, reduce HIV mother to child transmissions, reduce and at least delay child bride marriages, and hopefully also improve the status of girls and women in society, especially as more may become able to access a more thorough school education for younger girls, to a higher age, and later, Higher Education.

Finally, the world is changing, and the religious social formations must change with it, not least in the area of the positive propagation of healthy living, which includes access to modern-day biomedical health systems. This research suggests that the members of the Joahnne Marange Apostolic Church have been doing that for some years now. So, the conclusion is that, despite the 70year old belief and doctrinal hegemony of the church over its members, it appears that this hegemony is waning. It is being challenged by new forms of health information and education, and representative change agents. Amongst others, as pointed out, the main result is a remarkable increase in the levels of health and well-being of the general population.

\section{References}

Anderson, A, 2001. African Reformation: African Initiated Christianity in the $20^{\text {th }}$ Century. Trenton: Africa World Press.

Bourdillon, M.F.C. 1976. The Shona Peoples: An Ethnography of Contemporary Shona, with Special Reference to their Religion. Gweru: Mambo Press.

Chakawa, J. 2010. Church in Marange Area of Zimbabwe. Zimbabwe Social Science Review 1,2.

Chitando, E. 2007, Living with Hope: African Churches and HIV/AIDS. Geneva Switzerland: WCC Publications, World Church.

Daneel, M.L. 1971. Old and New in Southern Shona Independent Churches:

Volume 1: Background and Rise of the Major Movements. The Hague: Morton.

Hastings, A. 1979. History of African Christianity 1950-1975. Cambridge: Cambridge University Press.

Jules-Rosette, B. 1975. African Apostles: Ritual and Conversion in the Church of John Marange. London: Cornell University Press.

Machingura, F. 2011. The Shona Concept of Spirit Possession and the Pente- 
costal Phenomenon of Getting into the Spirit. Hope's Reason: A Journal of Apologetics 1,1 .

Mbiti, J.S. 1973. Love and Marriage in Africa. Harlow: Longman Group Limited.

Mbona, M. 2012. The Response of the Roman Catholic, Anglican and United Methodist Churches to HIV and AIDS in Manicaland Zimbabwe. Available at: https://researchspace.ukzn.ac.za/bitstream/handle/10413/ 9311/Mbona_Michael_2012.pdf?sequence=1\&isAllowed=y.

Mukonyora, I. 2007. Wandering in a Gendered Wilderness: Suffering and Healing in an African Initiated Church. New York: Peter Lang.

Muphree, M.W. 1971. Religious Interdependency among the Budya Vapositori. In Banet, D.B. (eds.): African Initiatives in Religion. Nairobi: East Africa Publishing House.

Phiri, I.A. \& S. Nadar (eds.) 2006. African Women, Religion and Health. Maryknoll, NY: Obis Books.

UNICEF 2001. Innocenti Research Centre. Early Marriage: Child Spouses 7. Florence, Italy: UNICEF.

Julius Musevenzi Department of Sociology University of Zimbabwe Mt. Pleasant Harare acrobat@sociologist.com 